\title{
Correction to: Circ-ASH2L promotes tumor progression by sponging miR-34a to regulate Notch1 in pancreatic ductal adenocarcinoma
}

Yan Chen ${ }^{1,2+}$, Zhonghu $\mathrm{Li}^{3+}$, Mengyun Zhang ${ }^{4+}, \mathrm{Bo} \mathrm{Wang}^{3}$, Jiaxin Ye ${ }^{3}$, Yang Zhang $^{3}$, Di Tang $^{3}$, Dandan $\mathrm{Ma}^{3}$, Weidong $\mathrm{Jin}^{3}$, Xiaowu Li ${ }^{1,5}$ and Shuguang Wang ${ }^{1 *}$

Correction to: J Exp Clin Cancer Res 38, 466 (2019) https://doi.org/10.1186/s13046-019-1436-0

Following publication of the original article [1], the authors identified some minor errors in image-typesetting in Fig. 4; specifically in Fig. 4a and Fig. 4h.

The corrected figure is given below. The correction does not have any effect on the results or conclusions of the paper.

\begin{abstract}
Author details
'Hepatobiliary Surgery Institute, Southwest Hospital, Army Medical University, Chongqing, China. ${ }^{2}$ Hepatobiliary Surgery Department, 958 Hospital of PLA,

Chongqing, Chongqing, China. ${ }^{3}$ Dept. general surgery, Central Theater Command General Hospital of PLA, Hubei, China. ${ }^{4}$ Department

Rheumatology of Integrated Traditional Chinese and Western Medicine, Central Theater Command general hospital of PLA, Hubei, China.

${ }^{5}$ Hepatobiliary Surgery \& Carson International Cancer Shenzhen University General Hospital \& Shenzhen University Clinical Medical Academy Center Shenzhen University, Shenzhen, China.
\end{abstract}

Published online: 16 April 2021

\section{Reference}

1. Chen Y, Li Z, Zhang M, et al. Circ-ASH2L promotes tumor progression by sponging miR-34a to regulate Notch1 in pancreatic ductal adenocarcinoma. J Exp Clin Cancer Res. 2019;38:466 https:/doi.org/10.1186/s13046-019-1436-0.

\footnotetext{
The original article can be found online at https://doi.org/10.1186/s13046019-1436-0.

* Correspondence: sgwangxnyy@sina.com

${ }^{\dagger}$ Yan Chen, Zhonghu Li and Mengyun Zhang contributed equally to this work.

${ }^{1}$ Hepatobiliary Surgery Institute, Southwest Hospital, Army Medical University, Chongqing, China
}

C C The Author(s). 2021 Open Access This article is licensed under a Creative Commons Attribution 4.0 International License, which permits use, sharing, adaptation, distribution and reproduction in any medium or format, as long as you give appropriate credit to the original author(s) and the source, provide a link to the Creative Commons licence, and indicate if changes were made. The images or other third party material in this article are included in the article's Creative Commons licence, unless indicated otherwise in a credit line to the material. If material is not included in the article's Creative Commons licence and your intended use is not permitted by statutory regulation or exceeds the permitted use, you will need to obtain permission directly from the copyright holder. To view a copy of this licence, visit http://creativecommons.org/licenses/by/4.0/ The Creative Commons Public Domain Dedication waiver (http://creativecommons.org/publicdomain/zero/1.0/) applies to the data made available in this article, unless otherwise stated in a credit line to the data. 


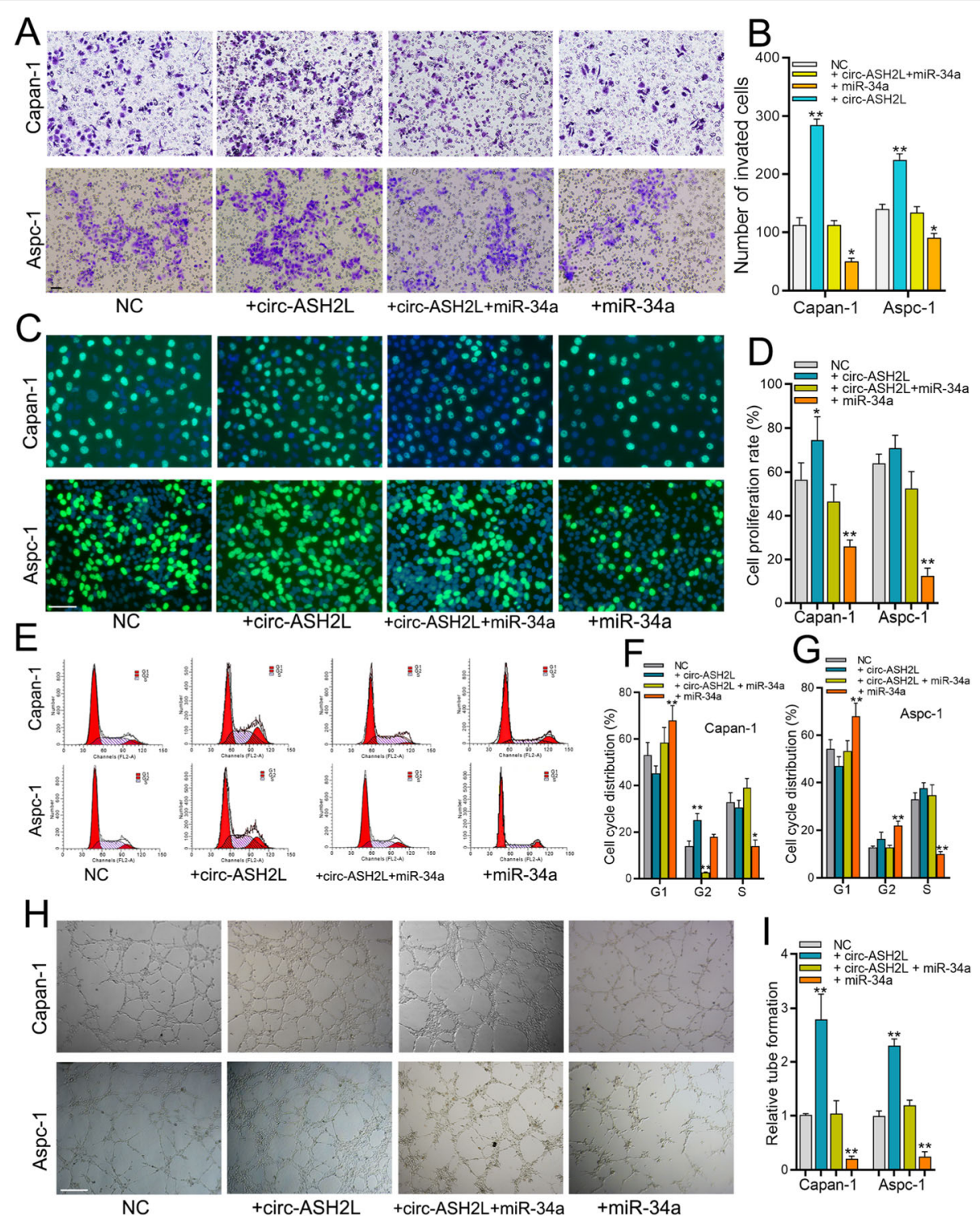

Fig. 4 a-b The invasion abilities of indicate treated Capan-1 (a) and Aspc-1 cells (b) were measured by transwell assays. Scale bars $=50 \mu \mathrm{m}$. $\mathbf{c}-\mathbf{d}$ The proliferation abilities of indicate treated Capan-1 (c) and Aspc-1 cells (d) were measured by EdU assays. Scale bars $=50 \mu \mathrm{m}$. $\mathbf{e}-\mathbf{g}$ The indicate treated Aspc-1 and Capan-1 cells (e) were stained by propidium iodide and analyzed using flow cytometry, the statistical results of Aspc-1 (f) and Capan-1 (g) cells were showed in right column. $\mathbf{h}-\mathbf{i}$ The in vitro angiogenesis abilities of indicated treated Capan-1 and Aspc-1 cells were measured by tube-formation assays of HUVECS cells (h), and the statistical result was showed in right column (i) 